\title{
Regulation of apoptosis: involvement of Bcl-2-related proteins
}

\author{
Tomasz Moty1 \\ Department of Animal Physiology, Veterinary Faculty, Warsaw Agricultural University, \\ Nowoursynowska 166, 02-787 Warsaw, Poland
}

(Received 1 July 1998; accepted 2 December 1998)

\begin{abstract}
This article is a concise review of up-to-date information and recent discoveries concerning structure, site of action, tissue distribution, biological effects and molecular mechanisms of Bcl-2 family proteins. Particular attention has been focused on the physiological aspect of $\mathrm{Bcl}-2$ protein function with emphasis on animal production and health. Bcl-2-related proteins are the principal regulators of apoptosis, acting through the control of ions $\left(\mathrm{K}^{+}, \mathrm{H}^{+}, \mathrm{Cl}^{-}, \mathrm{Ca}^{2+}\right)$ and reactive oxygen species fluxes, the release of apoptogenic factors from mitochondria (AIF, cytochrome $\mathrm{c}$ ) and the activation of the executors of apoptosis (caspases, DNases). The response of Bcl-2 proteins to pro- and antiapoptotic signals relies on the activation of transcription and translation, phosphorylation, proteolytic cleavage, interactions with $\mathrm{Bcl}$-2-related and other (structurally unrelated) proteins, translocation from the cytosol to intracellular membranes, and formation of permeability transition pores. (C) Inra/ Elsevier, Paris.
\end{abstract}

\section{Bcl-2 / Bax / apoptosis}

Résumé - Régulation de l'apoptose par les protéines apparentées à Bcl-2. Cette revue résume les connaissances et les découvertes récentes concernant les protéines de la famille $\mathrm{Bcl}-2$. Elle traite notamment de la structure et de la distribution cellulaires de ces protéines ainsi que de leurs effets biologiques, cibles et mécanismes d'action au niveau cellulaire et moléculaire. Elle souligne aussi le rôle de ces protéines dans la régulation des fonctions physiologiques et l'impact que cela peut avoir sur la production et la santé des animaux. Les protéines de type Bcl-2 exercent en effet une action majeure sur l'apoptose par le biais d'un contrôle des flux ioniques $\left(\mathrm{K}^{+}, \mathrm{H}^{+}, \mathrm{Cl}^{-}, \mathrm{Ca}^{2+}\right)$ et de la production des différentes formes d'oxygène réactifs. La libération de facteur apoptogène à partir des mitochondries (AIF, cytochrome C) et l'activation des enzymes impliqués dans l'apoptose (caspases, DNases) interviennent bien sûr également. La régulation de l'apoptose par les protéines Bcl-2 met en jeu de multiples signaux intracellulaires, interactions de ces protéines entre elles et avec d'autres protéines, phénomènes de transcription et traduction, mouvements de substrats du cytoplasme aux membranes intracellulaires et formation de pores transitoires de perméablité. (C) Inra/Elsevier, Paris.

Bcl-2 / Bax / apoptose 
1. APOPTOSIS AS A FUNDAMENTAL PROCESS IN CELL BIOLOGY

\subsection{Hallmarks of apoptosis}

Apoptosis is programmed, physiological, active or suicidal cell death. The term apoptosis, which in Greek means 'fallingoff' (like leaves from trees) was proposed by Kerr et al. [16] to emphasise the physiological nature of this process. Apoptosis is the complex of morphological and biochemical changes that occur in dying cells. The most characteristic morphological features of apoptosis are: cell shrinkage, the condensation of chromatin and its marginal distribution around the nuclear envelope, pycnosis and fragmentation of the nucleus, and the formation of apoptotic bodies (figure $l a-d)$. Unlike necrosis, apoptosis is a 'silent death' because the dying cells are immediately recognised and engulfed by phagocytes. The phagocytic recognition of apoptotic cells is facilitated by the loss of plasma membrane asymmetry which results in the aberrant exposure of phosphatidylserine residues at the cell surface. This early feature of apoptosis can be detected by the binding of fluorescein-conjugated annexin $\mathrm{V}$ to phosphatidylserine (figure le). The immediate phagocytosis of apoptotic cells is probably one of several reasons for the late discovery of programmed cell death. Apoptosis involves the coordinated destruction of cells with no effect on tissue function or activation of an inflammatory response, such that tissue function is uncompromised during remodelling. We observed that the number of visible apoptotic cells does not reflect the extent of cell loss, even during mammary tissue involution [44]. Unlike human or ani- mal tissue in vivo, apoptotic cells in cultures undergo secondary necrosis rather than phagocytosis (figure 1d). Vermes et al. [42] proposed the Greek term putrosis (corresponding to rotting of leaves after they have fallen off) to indicate the postapoptotic status primarily found under in vitro culture conditions where no phagocytes are present. The most typical biochemical feature of apoptosis is DNA fragmentation into 300 , $50 \mathrm{~kb}$ and often, but not always, oligonucleosomal fragments of multiples of 180-200 bp.

\subsection{Apoptosis in physiology and pathology}

Apoptosis is a fundamental process in cell biology and is an essential part of the growth, development and survival of all multicellular organisms. Paradoxically, the death of the unit (i.e. a single cell) is of benefit for the cell population as a whole. Apoptosis is a mechanism for the removal of unnecessary, aged, mutated and preneoplastic cells. Mitosis and apoptosis are in dynamic equilibrium, resulting in tissue remodelling: growth or involution (figure 2). Excessive cell replication and impaired apoptosis are characteristic of malignant proliferative diseases and autoimmune diseases. Excessive apoptosis plays a key role in the pathogenesis of neurodegenerative and neuromuscular diseases and AIDS. Recent work has shown that the induction of apoptosis may also be responsible for skeletal muscle atrophy in response to hindlimb unweighting [1]. It is unknown whether apoptosis is involved in the pathogenesis of prion diseases. The formation of complexes

Figure 1. Morphological and biochemical features of apoptosis: a, b, c, Chromatin condensation, pycnosis and fragmentation of nuclei, and formation of apoptotic bodies in L1210 mouse leukaemic cells (a, b) and HC-11 mouse mammary epithelial cells (c) stained with DAPI and sulphorhodamine (a) and propidium iodide with Hoechst-33342 (b, c); d, Fragmentation of the nucleus and secondary degenerative lesions in the cytoplasm and organelles of L1210 leukaemic cell (transmission electron microscopy, bar $2 \mu \mathrm{m}$ ); e, Exposure of phosphatidylserine residues at the surface of L1210 leukaemic 

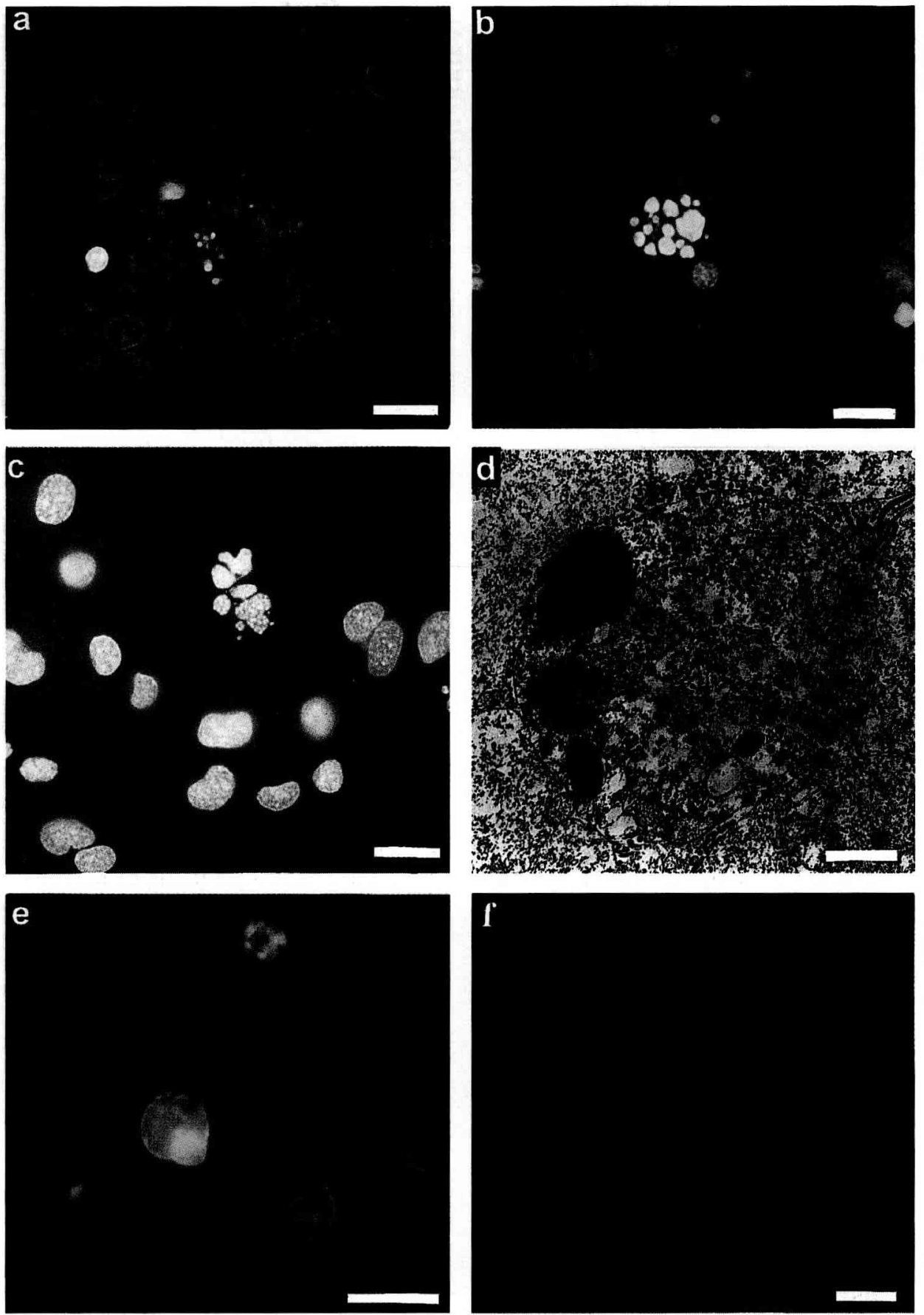

cells detected by FITC-conjugated annexin $\mathrm{V} ; \mathbf{f}, \mathrm{Bcl}-2$ protein in $\mathrm{HC} 11$ mouse mammary epithelial cells labelled with FITC-conjugated Mo-anti-Bcl-2 antibody. Bar $25 \mu \mathrm{m}$. 


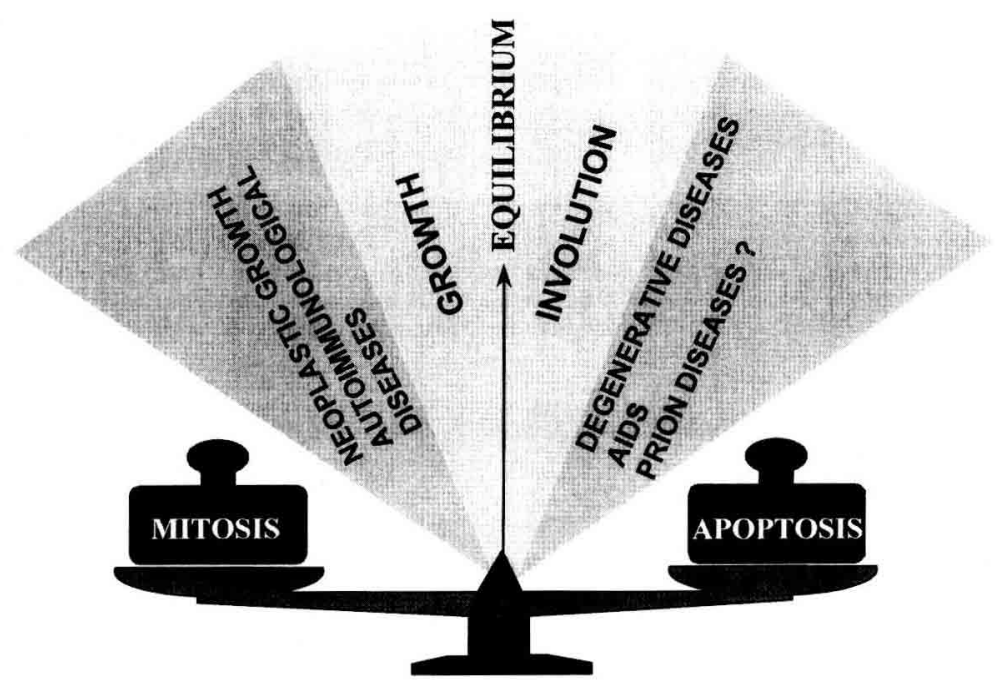

Figure 2. The balance between mitosis and apoptosis in the physiological and pathological range.

containing PrP and Bcl-2 family proteins suggests that this is the case [22].

Apoptosis is induced by diverse factors of four types: 1) hormones and cytokines (e.g. glucocorticoids, thyroid hormones, TNF $\alpha$, TGF $\beta 1$ ); 2) deficiency of growth and trophic factors; 3 ) cytotoxic factors (e.g. perforins, granzymes, enzyme inhibitors, cytostatic drugs, reactive oxygen species); 4) physical factors (e.g. radiation, hyperthermia, hydrodynamic tension).

Variety of apoptogenic agents requires many private pathways during the initiation of apoptosis. The effector (which is subject to regulation) and degradation (beyond regulation) stages are common to all apoptotic processes [20].

\section{Bcl-2 FAMILY PROTEINS: STRUCTURE AND APPEARANCE}

\subsection{Distribution in normal and neoplastic tissues}

Bcl-2-related proteins are the principal regulatory molecules acting at the effector stage of apoptosis (for review see [2, 20, $27,36])$. These proteins are either death antagonists (Bcl-2, Bcl-xL, Bcl-w, Bfl-1, Brag-1, Mcl-1 and A1) or death agonists (Bax, Bak, Bcl-xs, Bad, Bid, Bik and Hrk) [20]. The $b c l-2$ proto-oncogene was first discovered as a result of its involvement in the $\mathrm{t}(14 ; 18)$ chromosomal translocations common in non-Hodgkin's lymphoma [39, 40]. The $b c l-2$ gene, which is normally found on chromosome 18 at band $\mathrm{q} 21$, is brought into close contact with the IgH locus at chromosome $14 \mathrm{q} 32$. This brings this antiapoptotic gene under the control of strong enhancer elements, resulting in the overproduction of $\mathrm{Bcl}-2$ protein. $\mathrm{Bcl}-2$ protein is the most potent physiological inhibitor of apoptosis. Overexpression of $b c l-2$ occurs not only in haematological proliferative diseases, but also in many types of malignant solid tumours, and has been associated with the resistance of such tumours to radio- and chemotherapy [36]. Fifty-seven percent of breast cancers [46] and $27 \%$ of prostate cancers [4] overexpress $b c l-2$. A high level of $b c l-2$ expression occurs in standard leukaemic cell lines (L1210, MOLT-4, 
K562) and transformed cell lines (L6 rat skeletal myoblasts and $\mathrm{HC} 11$ mouse mammary epithelial cells - figure lff). The level of $\mathrm{Bcl}-2$ protein within individual cells differs and depends on cell line, cell cycle phase, availability of growth and trophic factors, and the effects of apoptogenic and antiapoptogenic stimuli.

Immunohistochemical analysis of $\mathrm{Bcl}$ 2-related proteins in normal tissues showed wide-spread and differential expression of $b c l-2, b a x, b c l-x$ and $m c l-1$ [27]. The patterns of bax and $b c l-2$ gene expression are only partially overlapping in mice tissues in vivo [19]. In general, bax - the bestknown promoter of apoptosis - is more ubiquitously expressed compared with $b c l$ 2 . The $b c l$-2 expression has been demonstrated first of all in stem cells with prolonged survival, e.g. bone marrow progenitor cells, and basal cell layer in epithelia of the gastrointestinal tract, breast and prostate [12]. In skeletal muscle $b c l-2$ is expressed in myogenic cells: myoblasts and adult satelite cells, but is not observed in multinucleate cells or differentiated cells that express myogenin or myosin heavy chain [8]. Therefore Bcl-2 protein could be useful in the identification of cells that are at an early stage of myogenesis and have properties of muscle stem cells.

\subsection{Structure and site of action}

The common feature of members of the $\mathrm{Bcl}-2$ family is the presence of four Bcl2 homology regions (BH1-BH4). These $\mathrm{BH}$ domains determine the capacity of $\mathrm{Bcl}-$ 2-related proteins to interact with each other, forming homo- or heterodimers, or to interact with other death-regulating proteins that are not structurally related to Bcl-2 (e.g. Bag 1 and Raf-1). Analysis of cells expressing various levels of Bcl-2 and Bax revealed that the degree of protection against apoptosis does not correlate with the number of Bcl-2-Bax heterodimers but the amount of $\mathrm{Bcl}-2$ that is free of $\mathrm{Bax}$ [32]. Most members of the Bcl-2 family have a carboxyterminal transmembrane region (except Bid and Bad). This domain causes Bcl-2-related proteins to post-translationally insert into intracellular membranes: the outer mitochondrial membrane, endoplasmic reticulum and nuclear envelope. The functional connection of Bcl2 protein with these membranes can be confirmed by undectable $b c l-2$ expression in human erythrocytes but detectable in nucleated frog or chicken red blood cells (unpublished). The transmembrane domain of the Bcl-2 protein may also have a significance beyond membrane insertion, as the principal site of homodimeric interaction and PrP binding [22]. The death-preventing effects of $\mathrm{Bcl}-2$ and the death-promoting effects of Bax are dependent on membrane targeting. Removal of the membrane-anchoring domain reduces the efficacy of $\mathrm{Bcl}-2$ and $\mathrm{Bax}$ as death regulators [13, 47]. $\mathrm{Bcl}-2$ is exclusively membrane-bound in murine thymocytes, whereas Bax is present predominantly in the cytosol and $\mathrm{Bcl}-\mathrm{xL}$ is present in both soluble and membrane-bound forms [14]. The induction of apoptosis by dexamethasone or $\gamma$-irradiation converts Bax and Bcl-xL from soluble to membranebound forms. It is possible that the membrane-bound $\mathrm{Bax}, \mathrm{Bcl}-2$ and $\mathrm{Bcl}-\mathrm{xL}$ proteins compete for the binding of an unknown protein in the membrane to promote cell death or survival [14]. The movement of Bax from the cytosol to the mitochondria during apoptosis is completed within $30 \mathrm{~min}$ and precedes cell shrinkage and chromatin condensation [45].

The structural similarity of Bcl-xL to the pore-forming colicins and diphtheria toxin domain (from X-ray crystallography and NMR spectroscopy) suggests that Bcl-2 proteins form pores in endoplasmic, mitochondrial and perinuclear membranes, regulated by signals dependent on voltage and $\mathrm{pH}$ [30]. Bcl-xL has a low level of interhelical interactions, three cavities and a marked hydrophobic cleft surrounded by walls rich in basic residues [3]. These unique structural features may favour its membrane 
insertion and involvement in channel formation. Bax homology modelling showed that this protein had the largest bottom hydrophobic cleft and that the hydrogen bonds stabilising the central helices had been lost, suggesting that Bax has a greater potential for membrane insertion than Bcl-2 or Bcl-xL [3]. These authors questioned pore formation by $\mathrm{Bcl}-\mathrm{xL}$ and $\mathrm{Bcl}-2$ and suggested that the function of these proteins was limited to the inhibition of pore formation by Bax or other pore-forming proteins via heterodimerisation. Bax and Bcl-2 each form ion channels in artificial membranes, which have distinct characteristics including ion selectivity, conductance, voltage dependence and rectification [37]. Bax is more selective for $\mathrm{Cl}^{-}$, as opposed to Bcl-2 for $\mathrm{K}^{+}$. Bcl-2 may also regulate $\mathrm{H}^{+}$fluxes to maintain mitochondrial transmembrane potential $(\Delta \Psi \mathrm{m})$ in the presence of $\Delta \Psi \mathrm{m}$ loss-inducing stimuli [38].

\subsection{Post-translational modifications}

The pro- and antiapoptotic function of Bcl-2 family proteins can be altered via the post-translational regulatory mechanisms such as phosphorylation and proteolytic cleavage [2]. The $\mathrm{Bcl}-2$ protein has been shown to be phosphorylated in vivo and the phosphorylated protein was found (depending on cell type, stimulus, local environment and differences in phosphorylation sites) either more or less efficient in promoting against apoptosis, compared to the unphosphorylated protein $[5,10]$. Serine phosphorylation of death agonist Bad in response to interleukin-3 resulted in binding to a rather ubiquitous cytosolic protein 14-3-3 [34, 48]. Only nonphosphorylated $\mathrm{Bad}$ was able to heterodimerise with Bcl$\mathrm{xL}$ at membrane sites and act as a death promoter. Lewis et al. [24] supported evidence that Bax is a substrate for specific serine/ threonine kinases in vitro, which suggests that the activity of Bax could be regulated by phosphorylation. Bax was phosphorylated by cAMP-dependent protein kinase (PKA) and to an apparent lesser degree by $\mathrm{p} 34^{\mathrm{cdc} 2}$ kinase and MAP p42 kinase.

\section{BIOLOGICAL EFFECTS AND POSSIBLE MECHANISMS OF Bcl-2-RELATED PROTEINS}

\subsection{Biochemical and physiological effects}

Overproduction of Bcl-2 causes a variety of inhibitory effects on apoptosis: 1) prevention of phosphatidylserine exposure at the cell surface; 2 ) inhibition of reactive oxygen species (ROS) generation and prevention of lipid peroxidation; 3 ) inhibition of caspase 3 and 6 activation; 4 ) inhibition of $\mathrm{Ca}^{+2}$ outflow from mitochondria and the endoplasmic reticulum, and of $\mathrm{Ca}^{+2}$ uptake into the nucleus; 5) inhibition of preapoptotic disruption of $\Delta \Psi \mathrm{m} ; 6$ ) prevention of outflow of apoptosis inducing factor (AIF) and cytochrome $\mathrm{c}$ from the mitochondrial intermembrane space [20].

In general, death agonists and antagonists of the Bcl-2 family of proteins function as a death/life balance. Cell exposure to apoptogenic stimuli is associated with an increase in the $\mathrm{Bax} / \mathrm{Bcl}-2$ ratio, whereas exposure to cell survival signals reduces the Bax/Bcl-2 ratio. Remodelling of the mammary gland is a good example of the regulation of $b a x$ and $b c l-2$ expression at the physiological level. It involves the periodic involution and growth of secretory tissue, regulated by a dynamic equilibrium between apoptogenic and mitogenic stimuli. Survival signals provided by EGF and prolactin increase $b c l-2$ and decrease bax expression in $\mathrm{HC}-11$ murine mammary epithelial cells [35]. Conversely, the administration of TGF- $\beta 1$, the auto- and paracrine apoptogenic factor, greatly increases Bax transcript levels in $\mathrm{HC}-11$ cultures treated or untreated with EGF or prolactin [44]. The levels of Bcl-2-related proteins depend on the physiological status of the mammary tissue. For 
example, immunohistochemical analysis of goat mammary tissue has shown an increase of Bax protein content in mammary epithelial cells from early lactation to drying off period [44]. Similarly, mouse mammary gland involution is associated with a high level of Bax and a decrease of Bcl-2 protein [28]. Bax and Bcl-xs mRNA levels in mammary epithelial cells increase within the first day after weaning, coinciding with the induction of apoptosis [11]. Bcl-2, Bax and Bcl-x proteins are also apoptotic checkpoint regulators in ductal morphogenesis of the murine mammary gland [15].

\subsection{Mechanisms of action}

The chain of events triggering apoptosis at the effector stage and possible sites of $\mathrm{Bcl}-2$ action are presented in figure 3 . The main site of antiapoptotic Bcl-2 action is probably the outer mitochondrial membrane, where it prevents (by heterodimerisation) the incorporation of Bax into megachannels formed at the contact sites between the mitochondrial inner and outer membranes. The induction of apoptosis involves Bax protein binding and the formation of mitochondrial permeability transition pores which, in turn, facilitate the release of two apoptogenic proteins: apoptosis-inducing factor (AIF) and cytochrome $c$ and the efflux of ROS and $\mathrm{Ca}^{2+}$ from mitochondria. The relationship between AIF and cytochrome $\mathrm{c}$ remains unknown. AIF is a $50 \mathrm{kDa}$ protease which, alone, activates caspase 3 and nuclear endonuclease in vitro [20,47]. Unlike AIF, cytochrome $\mathrm{c}$, which was identified as an apoptosis-activating factor 2 (Apaf 2) [25], requires the cytosolic proteins, Apaf 1 and Apaf 3 to proteolytically activate caspase 3 $[41,50]$. Apaf- 1 is similar to Ced-4, the nematode protein regulating apoptosis in Caenorhabditis elegans. Vaux [41] proposed a speculative model for caspase activation in the presence of dATP, cytochrome $c$ (Apaf-2), Apaf-1 and Apaf-3 (an unidenti-

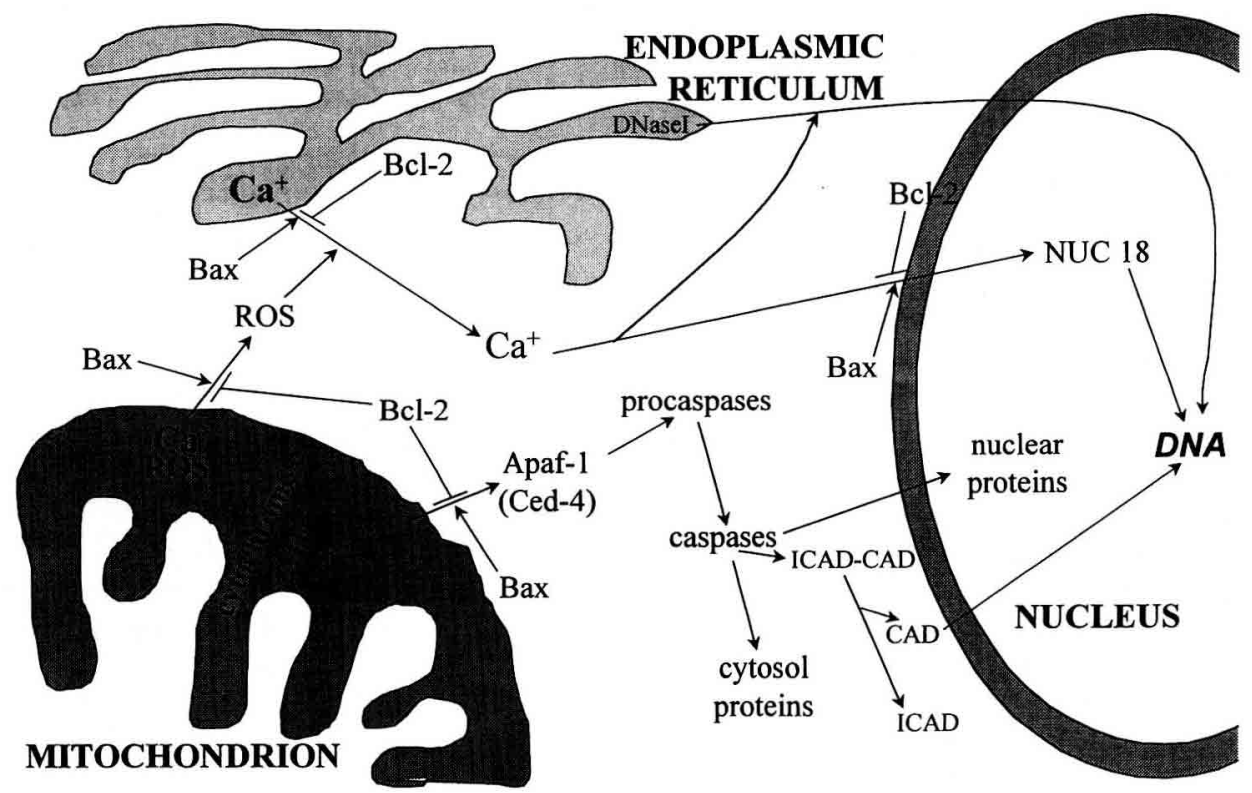

Figure 3. The regulation of apoptosis by $\mathrm{Bcl}-2$-related proteins. 
fied $45 \mathrm{kDa}$ protein). According to this model cytochrome $c$ and Apaf-3 activate Apaf-1, which in the presence of dATP, cleaves procaspase-3, removing the prodomain and leading to the assembly of other subunits into the proteolytically active conformation. Pan et al. [33] suggested that the caspase cascade triggered by cytochrome $c$ and Apaf- 1 possesses exquisite specificity and leads only to the activation of caspase- 3 , -7 and -9 . The Bcl-2 and $\mathrm{Bcl}-\mathrm{xL}$ proteins inhibit caspase activation by preventing the release of AIF and cytochrome $c$ from the intramitochondrial space and by direct binding to Apaf-1 (Ced-4). The structure of Bcl-xL shows that it should integrate into membranes and possibly interact with Ced-4 homologues [3]. Bcl-2-related death antagonists form complexes with Ced-4 and some procaspases, thereby inhibiting caspase activation [6]. Death agonists of the Bcl-2 protein family presumably disrupt these complexes, leading to the activation of caspases, triggering apoptosis. Overexpression of bax in COS-7 cells induces apoptosis dependent on the activation of caspase 3 [18]. Baxinduced apoptosis is abolished by $\mathrm{Bcl}-\mathrm{xL}$ and $\mathrm{Bcl}-2$, but only Bcl-xL inhibits the activation of caspase 3 . This suggests that the apoptosis induced by Bax overproduction is differentially regulated by Bcl-xL and $\mathrm{Bcl}-2$, which suppress cell death.

\subsection{Caspases - executors of apoptosis}

Caspases (cysteine aspartases) are a family of ten sulphydryl proteases, essential for apoptosis (for review see [17, 43]). However, there is evidence that they are not required in all cases of apoptosis [21,31]. Caspases may be divided into two classes based on the length of the $\mathrm{N}$-terminal prodomain: caspases $1,2,4,5,8$ and 10 have long prodomains and caspases $3,6,7$ and 9 have short prodomains [43]. The longprodomain class comprises 'regulatory' caspases involved in the initial steps of the apoptotic process and the activation of the short-prodomain class of caspases (death effector proteases). The short-domain caspases operate downstream from the cascade, cleaving cytoplasmic and nuclear substrates [43]. The tertiary structure and substrate binding site of caspase 8 have been predicted based on what is known of the structures of caspase 1 and caspase 3 [7]. The association of caspase-8 with cell surface death receptors suggests that it is a proximal regulator of apoptosis and provides insight into the possible use of this key cell death protease as a therapeutic target. A caspase-activated deoxyribonuclease (CAD) and its inhibitor (ICAD), the link between caspase cascade activation and chromosomal DNA fragmentation, have recently been identified in the cytoplasmic fraction of mouse lymphoma cells [9]. Caspases activated by apoptotic stimuli cleave ICAD, allowing CAD to enter the nucleus and degrade chromosomal DNA (figure 3). DFF-45 (DNA fragmentation factor), a $45 \mathrm{kDa}$ subunit of a heterodimeric protein that causes DNA fragmentation if it is digested by caspase-3, inhibits the activity of the activated nuclease [29].

\subsection{Regulation of $\mathrm{Ca}^{2+}$ and $\mathrm{ROS}$ fluxes}

Apoptosis in various model systems is associated with sustained increases in cytosolic $\mathrm{Ca}^{2+}$ concentration and, in some of these systems, DNA fragmentation and cell death can be prevented by intracellular $\mathrm{Ca}^{2+}$ buffering agents. $\mathrm{Ca}^{2+}$ concentration increases are involved in various stages of the apoptotic process: signal transduction, the activation of proteases, endonucleases (DNase I, NUC-18) and transglutaminase (for review see [26]). The $\mathrm{Bcl}-2$ protein either directly or indirectly regulates the flux of $\mathrm{Ca}^{2+}$ across the mitochondrial, endoplasmic reticulum and perinuclear membranes, thereby preventing $\mathrm{Ca}^{2+}$ signalling of apoptosis [23]. The molecular mechanism of intracellular $\mathrm{Ca}^{2+}$ regulation by $\mathrm{Bcl}-2$ protein is unclear, but a direct effect of Bcl- 
2 on $\mathrm{Ca}^{2+}$ channels is possible [26]. There is a relationship between concentration of ROS and $\mathrm{Ca}^{2+}$ release from intracellular stores. Oxidative stress increases $\mathrm{Ca}^{2+}$ release from the endoplasmic reticulum and mitochondria [23]. Bcl-2 may play a key role in this relationship by inhibiting ROS release from mitochondria (figure 3). Overexpression of bcl-2 protects the cell against apoptosis induced by ROS [13]. Overproduction of Bcl-2 and its insertion into the outer mitochondrial membrane prevents ROS-mediated changes in mitochondrial permeability and the release of AIF from the mitochondria into the cytosol [20]. Living cells are exposed to ROS generated intracellularly and ROS of extracellular origin. Oxidative stress caused by the hydrophilic peroxyl radical initiator, 2,2' azobis (2-amidinopropane) dihydrochloride (AAPH), is associated with the accumulation of ROS within the cell, peroxidation of cellular lipids and the induction of apoptosis in mouse L1210 lymphocytic leukaemic cells [49]. The degree of apoptosis is dependent on ROS concentration, cell exposure time and the availability of growth and trophic factors. It is interesting that the average $\mathrm{Bcl}-2$ level increases in the population of leukaemic cells surviving oxidative stress, which may be due to the deletion of cells with the weakest expression of $b c l-2$, which are more susceptible to oxidative stress. An increase in intracellular ROS concentration and the survival of cells with high Bcl-2 levels in FCSdeprived L1210 leukaemic cell cultures has also been observed (unpublished).

In conclusion, the regulation of the apoptotic process involves the activation of Bcl2-related proteins, occurring either at the transcriptional level or through post-translational modifications, in particular phosphorylation. Induction of apoptosis is associated with the shift of Bcl-2 family death agonists from the cytosol to intracellular membranes within minutes after apoptogenic stimuli. Bcl-2-related proteins, through the formation of membrane channels are involved in the regulation of ions $\left(\mathrm{K}^{+}, \mathrm{H}^{+}\right.$, $\left.\mathrm{Cl}^{-}, \mathrm{Ca}^{2+}\right)$ and ROS fluxes, the release of mitochondrial apoptogenic factors (AIF, cytochrome c) and the activation of the executors of apoptosis (caspases, DNases).

\section{ACKNOWLEDGEMENT}

I thank Wioletta Zimowska for technical assistance in preparation of the manuscript.

\section{REFERENCES}

[1] Allen D.L., Linderman J.K., Roy R.R., Bigbee A.J., Grindeland R.E., Mukku V., Edgerton V.R., Apoptosis: a mechanism contributing to remodelling of skeletal muscle in response to hindlimb unweighting, Am. J. Physiol. 273 (1997) C579-C587.

[2] Allen R.T., Cluck M.W., Agrawal D.K., Mechanisms controlling cellular suicide: role of $\mathrm{Bcl}-2$ and caspases, Cell Mol. Life Sci. 54 (1998) 427-445.

[3] Aritomi M., Kunishima N., Inohara N., Ishibashi Y., Ohta S., Morikawa K., Crystal structure of rat Bcl-xL, J. Biol. Chem. 272 (1997) 27886-27892.

[4] Bauer J.J., Sesterhenn I.A., Mostofi F.K., Mcleod D.G., Srivastava S., Moul J.W., Elevated levels of apoptosis regulator proteins $\mathrm{p} 53$ and $\mathrm{Bcl}-2$ are independent prognostic biomarkers in surgically treated clinically localized prostate cancer, J. Urol. 156 (1996) 151 1-1516.

[5] Chen C.Y., Faller D.V., Phosphorylation of Bcl-2 protein and association with $\mathrm{p} 21$ Ras in Rasinduced apoptosis, J. Biol. Chem. 271 (1996) 2376-2379.

[6] Chinnaiyan A.M., O' Rourke K., Lane Br., Dixit V.M., Interaction of CED-4 with CED-3 and CED-9: a molecular framework for cell death, Science 275 (1997) 1122-1 126.

[7] Chou K.-C., Jones D., Heinrikson R.L., Prediction of the tertiary structure and substrate binding site of caspase-8, FEBS 419 (1997) 49-54.

[8] Dominov J.A., Dunn J.J., Miller J.B., Bcl-2, apoptosis regulators and skeletal muscle stem cells, Proceedings of International Symposium on: Post-natal myogenesis: satellite cells in action!, Swissotel, Boston, USA, 13-16 August, 1998.

[9] Enari M., Sakahira H., Yokoyama H., Okawa K., Iwamatsu A., Nagata S., A caspase-activated DNase that degrades DNA during apoptosis, and its inhibitor ICAD, Nature 391 (1998) $43-50$. 
[10] Haldar S., Jena N., Croce C.M., Inactivation of Bcl-2 by phosphorylation, Proc. Natl. Acad. Sci. USA 92 (1995) 4507-4511.

[11] Heermeier K., Benedict M., Li M., Furth P., Nanez G., Hennighausen I., Bax and Bcl-xs are induced at the onset of apoptosis in involuting mammary epithelial cells, Mech. Dev. 56 (1996) 197-207.

[12] Hockenbery D.M., Zutter M., Hickey W., Nahm M., Korsmeyer S.J., Bcl-2 protein is topographically restricted in tissues characterised by apoptotic cell death, Proc. Natl. Acad. Sci. USA 88 (1991) 6961-6965.

[13] Hockenbery D.M., Oltvai Z.N., Yin X.-M., Milliman C.L., Korsmeyer S.J., Bcl-2 functions in an antioxidant pathway to prevent apoptosis, Cell 75 (1993) 241-251.

[14] Hsu Y.-T., Wolter K.G., Youle R.J., Cytosolto-membrane redistribution of $\mathrm{Bax}$ and $\mathrm{Bcl}-\mathrm{xL}$ during apoptosis, Biochemistry 94 (1997) 3668-3672.

[15] Humphreys R.C., Krajewaka M., Krnacik S., Jaeger R., Weiher H., Krajewski S., Reed J.C., Rosen J.M., Apoptosis in the terminal endbud of the murine mammary gland: a mechanism of ductal morphogenesis, Development 122 (1996) 4013-4022.

[16] Kerr J.F., Wyllie A.H., Currie A.R., Apoptosis: a basic biological phenomenon with wide-ranging implications in tissue kinetics, Br. J. Cancer 26 (1972) 239-257.

[17] Kidd V.J., Proteolytic activities that mediate apoptosis, Annu. Rev. Physiol. 60 (1998) 533-573.

[18] Kitanaka C., Namiki T., Noguchi K., Mochizuki T., Kagaya S., Chi S., Hayashi A., Asai A., Tsujimoto Y., Kuchino Y., Caspase-dependent apoptosis of COS-7 cells induced by Bax overexpression: differential effects of Bcl-2 and Bcl-xL on Bax-induced caspase activation and apoptosis, Oncogene 15 (1997) 1763-1772.

[19] Krajewski S., Krajewska M., Shabaik A., Miyashita T., Wang H.G., Reed J.C., Immunohistochemical determination of in vivo distribution of Bax, a dominant inhibitor of Bcl-2, Am. J. Pathol. 145 (1994) 1323-1336.

[20] Kroemer G., The proto-oncogene $\mathrm{Bcl}-2$ and its role in regulating apoptosis, Nat. Med. 3 (1997) 614-619.

[21] Kuida K., Lippke J.A., Ku G., Harding M.W., Livingston D.J., Su M.S., Flavell R.A., Altered cytokine export and apoptosis in mice deficient in interleukin- 1 beta-converting enzyme, Science 267 (1995) 2000-2003.

[22] Kurschner C., Morgan J.I., Analysis of interaction sites in homo- and heteromeric complexes containing Bcl-2 family members and the cellular prion protein, Mol. Brain Res. 37 (1996) 249-258.
[23] Lam M., Dubyak G., Chen L., Nunez G., Miesfeld R.L., Distelhorst C.W., Evidence that Bcl-2 represses apoptosis by regulating endoplasmic reticulum-associated $\mathrm{Ca}^{2+}$ fluxes, Med. Sci. 91 (1994) 6569-6573.

[24] Lewis S., Bethell S.S., Patel S., Martinou J.-C., Antonsson B., Purification and biochemical properties of soluble recombinant human Bax, Prot. Express. Purif. 13 (1998) 120-126.

[25] Liu X., Kim C.N., Yang J., Jemmerson R., Wang $X$., Induction of apoptotic program in cell-free extracts: requirement for $\mathrm{dATP}$ and cytochrome c, Cell 86 (1996) 147-157.

[26] McConkey D.J., Orrenius S., The role of calcium in the regulation of apoptosis, J. Leuk. Biol. 59 (1996) 775-783.

[27] McDonnell T.J., Beham A., Sarkiss M., Andersen M.M., Lo P., Importance of Bcl-2 family in cell death regulation, Experientia 52 (1996) 1008-1017.

[28] Merlo G.R., Cella N., Hynes N.E., Apoptosis is accompanied by changes in $\mathrm{Bcl}-2$ and $\mathrm{Bax}$ expression, induced by loss of attachment, and inhibited by specific extracellular matrix proteins in mammary epithelial cells, Cell Growth Diff. 8 (1997) $251-260$.

[29] Mitamura S., Ikawa H., Mizuno N., Kaziro Y., Itoh $\mathrm{H}$., Cytosolic nuclease activated by caspase- 3 and inhibited DFF-45, Biochem. Biophys. Res. Comm. 243 (1998) 480-484.

[30] Muchmore S.W., Satter M., Liang H., Meadows R.P., Harlan J.E., Yoon H.S., Nettesheim D., Changs B.S., Thompson C.B., Wong S.-L., Ng S.-C., Fesik S.W., X-ray and NMR structure of human $\mathrm{Bcl}-\mathrm{xL}$, an inhibitor of programmed cell death, Nature 381 (1996) 335-341.

[31] Nicholson D.W., Ali A., Thornberry N.A., Vaillancourt J.P., Ding C.K., Gallant M., Gareau Y., Griffin P.R., Labelle M., Lazebnik Y.A., Identification and inhibition of the ICE/CED-3 protease necessary for mammalian apoptosis, Nature 376 (1995) 37-43.

[32] Otter I., Conus S., Ravn U., Rager M., Olivier R., Monney L., Fabbro D., Borner Ch., The binding properties and biological activities of $\mathrm{Bcl}-2$ and Bax in cells exposed to apoptotic stimuli, J. Biol. Chem. 273 (1998) 6110-6120.

[33] Pan G., Humke E.W., Dixit V.M., Activation of caspases triggered by cytochrome $\mathrm{c}$ in vitro, FEBS Lett. 426 (1998) 151-154.

[34] del Peso L., Gonzalez-Garcia M., Page C., Herrera R., Nunez G., Intraleukin-3-induced phosphorylation of $\mathrm{BAD}$ through the protein kinase Akt, Science 278 (1997) 687-689.

[35] Ploszaj T., Motyl T., Orzechowski A., Zimowska W., Wareski P., Skierski J., Zwierzchowski L., Antiapoptotic action of prolactin is associated with up-regulation of $\mathrm{Bcl}-2$ and down-regulation of $\mathrm{Bax}$ in $\mathrm{HCl} 1$ mouse mammary epithelial cells, Apoptosis 3 (1998) 1-10. 
[36] Reed C.J., Mechanisms of BcI-2 family protein function and dysfunction in health and disease, Behring Inst. Mitt. 97 (1996) 72-100.

[37] Schlesinger P.H., Gross A., Yin X.-M., Yamamoto K., Saito M., Waksman G., Korsmeyer S.J., Comparison of the ion channel characteristics of proapoptotic Bax and antiapoptotic Bcl-2, Proc. Natl. Acad. Sci. USA 94 (1997) 11357-11362.

[38] Shimizu S., Eguchi Y., Kamiike W., Funahashi Y., Mignon A., Lacronique V., Matsuda H., Tsujimoto Y., Bcl-2 prevents apoptotic mitochondrial dysfunction by regulating proton flux, Proc. Natl. Acad. Sci. USA 95 (1998) 1455-1459.

[39] Tsujimoto Y., Croce C.M., Analysis of the structure, transcripts, and protein products of $\mathrm{Bcl}-2$, the gene involved in human follicular lymphoma, Proc. Natl. Acad. Sci. 83 (1986) 5214-5218.

[40] Tsujimoto Y., Cossmann J., Jaffe E., Croce C., Involvement of the Bcl-2 gene in human follicular lymphoma, Science 228 (1985) 1440-1443.

[41] Vaux D.L., CED-4 - the third horseman of apoptosis, Cell 90 (1997) 389-390.

[42] Vermes I., Haanen C., Richel D.J., Schaafsma M.R., Kalsbeek-Batenburg E., Reutelingsperger C.P., Apoptosis and secondary necrosis of lymphocytes in culture, Acta Haematol. 98 (1997) 8-13.

[43] Villa P., Kaufmann S.H., Earnshaw W.C., Caspases and caspase inhibitors, Trends Biochem. Sci. 22 (1997) 388-393.

[44] Wareski P., Motyl T., Ploszaj T., Janczewska S., Orzechowski A., Ryniewicz Z., Regulation of bax expression in mammary gland remodelling,
Proceedings of International Symposium on: Development of adaptations in the gastrointestinal tract and in the whole body in growing animals regarding food utilization and health, Paris, France, 23-24 June, 1998.

[45] Wolter K.G., Hsu Y.-T., Smith C.L., Nechush$\tan$ A., Xi X.-G., Youle R.J., Movement of Bax from the cytosol to mitochondria during apoptosis, J. Cell Biol. 139 (1997) 1281-1292.

[46] Yamaguchi A., Maehara M., Goi T., Katayama K., Hirose K., Nakagawara G., Bcl-2 protein expression in breast cancer and its relationship to prognosis, Int. J. Oncol. 10 (1997) 581-584.

[47] Zamzami N., Hirsch T., Dallaporta B., Petit P.X., Kroemer G., Mitochondrial implication in accidental and programmed cell death: apoptosis and necrosis, J. Bioenerg. Biomembr. 29 (1997) 185-193.

[48] Zha J., Harada H., Yang E., Jockel J., Korsmeyer S.L., Serine phosphorylation of death agonist $\mathrm{BAD}$ in response to survival factor results in binding to 14-3-3 not BCL-XL, Cell 87 (1996) 619-628.

[49] Zimowska W., Motyl T., Skierski J., Balasinska B., Ploszaj T., Orzechowski A., Filipecki M., Apoptosis and $\mathrm{Bcl}-2$ protein changes in L1210 leukaemic cells exposed to oxidative stress, Apoptosis 2 (1997) 529-539.

[50] Zou H., Henzel W.J., Liu X., Lutschg A., Wang X., Apaf-1, a human protein homologous to $C$. elegans CED-4, participates in cytochrome c-dependent activation of caspase-3, Cell 90 (1997) 405-413. 